J. Japan. Assoc. Min.

Petr. Econ. Geol.

73, $176-179,1978$

\title{
HIGHLY MAGNESIAN DUNITE FROM THE MINEOKA BELT, CENTRAL JAPAN
}

\author{
SHOJI ARAI \\ Geoscience Institute, Faculty of Science, Shizuoka University, Shizuoka \\ and TAKaShI UCHIDA \\ Japan Petroleum Exploration Co., Ltd.
}

\section{INTRODUGTION}

Ultramafic rocks emplaced in the Mineoka Group, perhaps Paleogene in age (Kanehira, 1976), of the Mineoka belt, Chiba Prefecture, are characterized by plagioclase-bearing harzburgite (Uchida and Arai, in prep.), and dunite is very rare. Extremely magnesian character of dunite from the Mineoka belt is found, and chemical characteristics and genesis of the highly magnesian dunite are discussed.

\section{MODE OF OGGURRENGE}

Dunite reported here is stratified with harzburgite at the exposure (Locality 51, Fig. 1). At the weathered surface, dunite is yellowish brown and harzburgite is dark to yellowish green. Both dunite and harzburgite at the exposure are, as at the other exposures of ultramafic rocks of the Mineoka belt, intesely fragmentary or brecciated, being aggregate of slicken-sided blocks with powdered serpentine matrix.

\section{Description OF THE DUNITE}

Dunite is severely serpentinized and is almost composed of serpentine (lizarditechrysotile), brucite, and opaque minerals
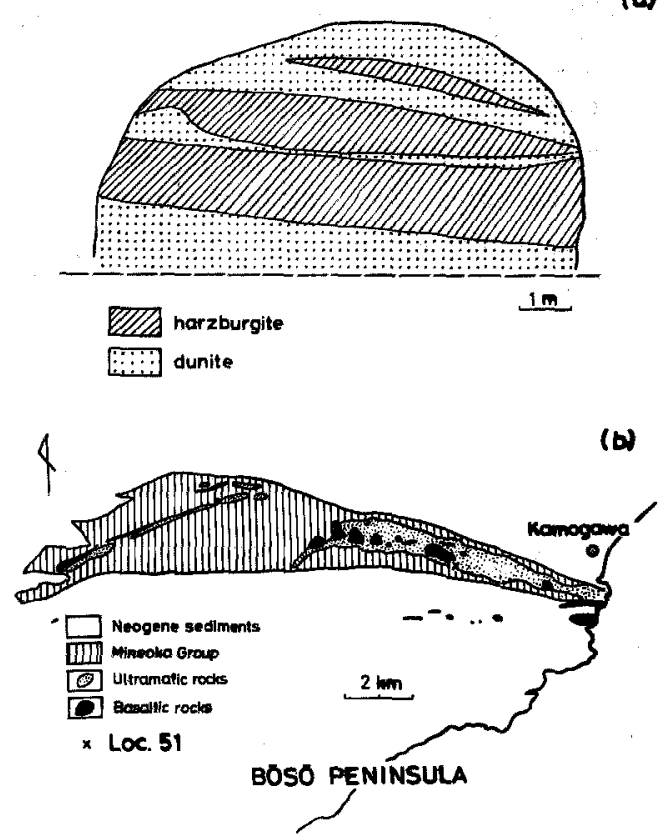

Fig. 1 (a) Schematic sketch of the exposure of stratified harzburgite and highly magnesian dunite (Locality 51). (b) Index map showing the Locality 51 of the Mineoka belt, Boso Peninsula (Geol. Surv. Japan, 1976).

(mainly mangetite). Thin veins of brucite and magnetite are frequently observed. The mode is as follows; olivine $3.5 \%$, chromian spinel $1.2 \%$, serpentine $87.2 \%$ and brucite $8.2 \%$. Primary minerals are olivine 
and chromian spinel. Streaks of chromitite are occasionally found in the dunite blocks. Pseudomorph after pyroxene (orthopyropyroxene ?) accompanied by chromian spinel is sometimes present. Talc and plagioclase (or saussurite) are not found. Pale green ph[ogopite is found, associated with chromian spinel. Relict olivine is clear and free from dusty inclusion which is one of the criteria of the olivine produced by deserpentinization (Arai, 1975). Chromian spinel is brown in thin section and shows various morphological characteristics. In addition to the sparse large euhedral grains, small euhedral ones are ubiquitous. Chromian spinel also occurs as very thin discrete rectangular lamella and as vermicular lamella in olivine. The latter lamella is possibly a symplectite-like intergrowth with other phase(s), such as pyroxene. Chromian spinel lamellae in olivine were also reported from dunite and harzburgite of Iwanai-dake, Hokkaido (Arai, 1978).

Associated harzburgite bears plagioclase (now altered to saussurite) and is the most common rock type of the ultramafics of the Mineoka belt (Uchida and Arai, in prep.).

\section{MineRALOGY}

Constituent minerals were analyzed with JEOL EPMA Model JXA-5 according to the procedures of Nakamura and Kushiro (1970).

Olivine is highly magnesian, and its Fo component is higher than $94 \%$ (Table 1). $\mathrm{NiO}$ content is also high, 0.5 to 0.7 wt. $\%$ (Table 1). It is noted that $\mathrm{CaO}$ content is relatively high and often exceeds 0.1 wt. \% (Table 1). $\mathrm{Al}$ and $\mathrm{Cr}$ are sometimes detectable although the contamination of submicroscopic chromian spinel lamella is possible. Olivine in harzburgite is striking-
Table 1 Selected EPMA analyses of constituent minerals of the highly magnesian dunite.

\begin{tabular}{|c|c|c|c|c|c|}
\hline No. & I & 2 & 3 & 4 & 5 \\
\hline $\mathrm{SiO}_{2}$ & 40.3 & 39.9 & 0.00 & 0.15 & 36.7 \\
\hline $\mathrm{TiO}_{2}$ & 0.00 & 0.00 & 0.19 & 0.12 & 0.63 \\
\hline $\mathrm{Al}_{2} \mathrm{O}_{3}$ & 0.00 & 0.00 & 21.0 & 16.6 & 15.5 \\
\hline $\mathrm{Cr}_{2} \mathrm{O}_{3}$ & 0.00 & 0.00 & 49.5 & 50.7 & 3.1 .6 \\
\hline Feo* & 5.71 & 5.65 & 12.3 & 17.4 & 2.27 \\
\hline Mno & 0.10 & 0.08 & 0.34 & 0.63 & 0.01 \\
\hline $\mathrm{MgO}$ & 52.4 & 52.7 & 15.9 & 13.6 & 25.6 \\
\hline $\mathrm{CaO}$ & 0.13 & 0.12 & 0.00 & 0.00 & 0.09 \\
\hline $\mathrm{Na}_{2} \mathrm{O}$ & nd & nd & nd & nd & 0.71 \\
\hline $\mathrm{k}_{2} \mathrm{O}$ & nd & nd & nd & nd & 7.27 \\
\hline Nio & 0.58 & 0.53 & 0.08 & 0.00 & 0.47 \\
\hline Total & 99.1 & 99.0 & 99.3 & 99.2 & 92.4 \\
\hline \multicolumn{6}{|c|}{ Number of atoms } \\
\hline 0 & 4.000 & 4.000 & 4.000 & 4.000 & 11.000 \\
\hline si & 0.982 & 0.974 & 0.000 & 0.005 & 2.668 \\
\hline Al & 0.000 & 0.000 & 0.758 & 0.625 & 1.330 \\
\hline Ti & 0.000 & 0.000 & 0.005 & 0.003 & 0.342 \\
\hline$C r$ & 0.000 & 0.000 & 1.200 & 1.279 & 0.182 \\
\hline $\mathrm{Fe}$ & 0.117 & 0.116 & 0.316 & 0.465 & 0.138 \\
\hline $\mathrm{Mn}$ & 0.002 & 0.002 & 0.009 & 0.017 & 0.001 \\
\hline $\mathrm{Mg}$ & 1.902 & 1.921 & 0.727 & 0.646 & 2.768 \\
\hline $\mathrm{Ca}$ & 0.004 & 0.003 & 0.000 & 0.000 & 0.007 \\
\hline $\mathrm{Na}$ & $\longrightarrow$ & - & $\longrightarrow$ & 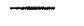 & 0.010 \\
\hline K & - & $\longrightarrow$ & $\longrightarrow$ & - & 0.674 \\
\hline $\mathrm{Ni}$ & 0.01 .1 & 0.010 & 0.002 & 0.000 & 0.027 \\
\hline Mg* & 0.942 & 0.943 & 0.727 & 0.643 & 0.952 \\
\hline $\mathrm{Cr} / \mathrm{Cr}+$ & & & 0.612 & 0.672 & \\
\hline $\mathrm{Fe} " 1 / \mathrm{Cr}$ & & & 0.021 & 0.053 & \\
\hline
\end{tabular}

$\mathrm{FeO}^{*}$ and $\mathrm{Fe}^{*}$, total iron as $\mathrm{FeO}$ and $\mathrm{Fe}$, respectively. nd, not determined. $\mathrm{Mg}^{*}$, $\mathrm{Mg} / \mathrm{Mg}+\mathrm{Fe}^{*}$ atomic ratio (Nos. 1, 2 \& 5) or $\mathrm{Mg} / \mathrm{Mg}+\mathrm{Fe}^{+2}$ atomic ratio (Nos. $3 \&$ 4). No. $1 \&$ No. 2, olivine. No. 3, large euhedral spinel. No. 4, small euhedral spinel. No. 5, phlogopite.

ly uniform regardless of the sampling locality, $\mathrm{Fo}_{91}$ to $\mathrm{Fo}_{92}$, at the Mineoka belt (Uchida and Arai, in prep.). $\mathrm{NiO}$ content of harzburgite olivine is 0.3 to $0.4 \mathrm{wt}$. \% and $\mathrm{CaO}$ content is far lower than $0.1 \mathrm{wt}$. \% (Uchida and Arai, in prep.). Olivine in harzburgite does not bear any lamellar inclusions of chromian spinel.

Chromian spinel in the dunite is more Cr-enriched than that in harzburgite from 
the Mineoka belt (Uchida and Arai, in prep.). $\mathrm{Cr} /(\mathrm{Cr}+\mathrm{Al})$ atomic ratio of the dunite spinel is higher than 0.6. Large euhedral grain tends to be lower in $(\mathrm{Al} / \mathrm{Al}+\mathrm{Cr})$ ratio and $\mathrm{Fe}^{\prime \prime \prime}$ content than small euhedral grain (Table 1). The latter is chemically zoned and $\mathrm{Cr} /(\mathrm{Cr}+\mathrm{Al})$ ratio often rapidly changes at the margin. Large euhedral grain is magnesian and $\mathrm{Mg} / \mathrm{Mg}+\mathrm{Fe}^{2+}$ atomic ratio is around 0.7. Small euhedral grain is less magnesian (Table 1 ). $\mathrm{TiO}_{\mathrm{a}}$ content ranges from 0.1 to $0.2 \mathrm{wt} \%$ (Table 1 ).

Phlogopite is characterized by the enrichment of $\mathrm{Mg}$ and $\mathrm{Cr}$, and $\mathrm{Ti}$ content is very low (Table 1). It is deficient in $(\mathrm{K}+$ $\mathrm{Na}+\mathrm{Ca}$ ), of which number of atoms is 0.781 for $\mathrm{O}=11$ (on anhydrous basis), to fulfil the phlogopite stoichiometry.

Brucite and serpentine. Brucite is the least magnesian silicate in the dunite described here. $\left(\mathrm{Mg} / \mathrm{Mg}+\mathrm{Fe}^{*}\right)$ (total $\mathrm{Fe}$ ) atomic ratios of coexisting brucite and serpentine are 0.913 and 0.958 respectively. $\mathrm{K}_{\mathrm{D}}=\left(\mathrm{X}_{\mathrm{Mg}_{\mathrm{g}}} / \mathrm{X}_{\mathrm{Fe}}\right)^{\text {brucite }}\left(\mathrm{X}_{\mathrm{Fe}} / \mathrm{X}_{\mathrm{Mg}}\right)^{\text {serpentine }}$ about 0.46 and is comparable to the ordinary value (0.5) in serpentinized dunite (Evans and Trommsdorff, 1972).

\section{Discussion}

Dunite with olivine of $\mathrm{Fo}_{94}$ described here is one of the most magneisan rocks of all ultramafics (alpine-type or nodule) ever documented. Sinton (1977) also reported a magnesian olivine $\left(\mathrm{Fo}_{\mathbf{9 4 . 7}}\right)$ in dunite from Red Moustain, New Zealand. Assuming the distribution coefficient $K_{\mathrm{D}}=\left(\mathrm{X}_{\mathrm{Mgo}} / \mathrm{X}_{\mathrm{FeO}}\right)$ liquid. $\left(\mathrm{X}_{\mathrm{Fgo}} / \mathrm{X}_{\mathrm{MgO}}\right)^{\text {olivine }}$ of 0.3 (Roeder and Emslie, 1970), the $\mathrm{Mg} /\left(\mathrm{Mg}+\mathrm{Fe}^{2+}\right)$ atomic ratio of the liquid coexisting with olivine of $\mathrm{Fo}_{\text {94.2 }}$ (Table 1), is about 0.83. The $\mathrm{Mg}$ / $\left(\mathrm{Mg}+\mathrm{Fe}^{2+}\right)$ value of 0.83 is too high for the ordinary basalt and is comparable with those of komatiites (e.g. Arndt et al., 1977; Nisbet et al., 1977) or of some picritic basalts (e.g. Brooks and Hart, 1974). Olivine in komatiites is characterized by the high contents of $\mathrm{Ca}$ and $\mathrm{Cr}$ (Green et al., 1975; Arndt et al., 1977; Nisbet et al., 1977), which are consistent with the relatively high contents of $\mathrm{Ca}$ and $\mathrm{Cr}$ of olivine of the dunite described here, though $\mathrm{Cr}$ is now concentrated in spinel lamella (Arai, 1978). Picrite basalts, also distributed in the Mineoka Group, have the $\mathrm{Mg} /\left(\mathrm{Mg}+\mathrm{Fe}^{*}\right)$ ratio around 0.83 (Sameshima, 1970; Tazaki, 1975). If the bulk chemical composition of the picrite basalt exposed in the Mineoka belt represented that of liquid and $\mathrm{Fe}^{3+}$ content was almost nil, it is the most likely counterpart of the highly magnesian dunite described here.

The relationship of dunite and harzburgite observed at the exposure (Fig. 1) may have not been produced by the igneous activity, because the Fo content of olivine of the dunite $(>94)$ is too much different from that of the harzburgite $(<92)$. The stratification of dunite and harzburgite (Fig. 1) was probably formed by the post-igenous events, such as piling of tectonic sheets. It may not be impossible that dunite and harzburgite (Fig. 1) are alternating beds of ultramafic conglomerates or slumping deposits.

\section{REFERENCES}

Arai, S. (1975), Contact metamorphosed duniteharzburgite complex in the Chugoku district western Japan. Contrib. Mineral. Petrol., 52, $1-16$

(1978), Chromian spinel lamellae in olivine from the Iwanai-dake peridotite mass, Hokkaido, Japan. Earth \& Planet. Sci. Lett., 39, 267-273.

Arndt, N.T., Naldrett, A.J, and Pyke, D.R. (1977), Komatiitic and iron-rich tholeiitic lavas of Munro Township, northeast Ontario. J. Petrol. 18, 319-369

Brooks, C. and Hart, S.R. (1974), On the signifi- 
cance of komatiite: Geology, 2, 107-110.

Evans, B.W. and Trommsdorff, V. (1972), Der Einfluss des Eisens auf die Hydratisierung von Duniten. Schweiz. Mineral. Petrogr. Mitt., 52, 251-256.

Geological Survey of Japan (1976), Geological map of Tokyo Bay and adjacent areas $(1: 100,000)$.

Green, D.H., Nicholls, I.A., Viljoen, M.J. and Viljoen, R.P. (1975), Experimental demonstration of the existence of peridotitic liquids in earliest Archean magmatism. Geology, 3, 11-15.

Kanehira, K. (1976), Modes of occurrence of serpentinite and basalt in the Mineoka district, southern Boso Peninsula. Mem. Geol. Soc. Japan, 13, 43-50 (in Japanese with English abstract).

Nakamura, Y. and Kushiro, I. (1970). Compositional relations of coexisting orthopyroxene, pigeonite and augite in a tholeiitic andesite from Hakone volcano. Contrib. Mineral. Petrol., 26, 265-275.
Nisbet, E.G., Bickle, M.J. and Martin, A. (1977), The mafic and ultramafic lavas of the Belingwe. Greenstone Belt, Rhodesia. J. Petrol., 18, 521-566.

Roeder, P.L. and Emslie, R.F. (1970), Olivineliquid equilibrium. Contrib. Mineral. Petrol., 29, 275-289.

Sameshima, T. (1970), Picrite basalts from the Boso Peninsula. Absty. 77th Annul Meet. Gool. Soc. Japan, 266 (in Japanese).

Sinton, J.M. (1977), Equilbiration history of the basal alpine-type peridotite, Red Mountain, New Zealand. J. Petrol., 18, 216-246.

Tazaki, K. (1975), Chromian spinels in picrite basalt from Mineoka Tectonic Belt, Boso Peninsula, central Japan, J. Geol. Soc. Japan, 81, 399-406 (in Japanese with English abstract).

Uchida, T. and Arai, S. (in preparation), Petrology of ultramafic rocks from the Boso Peninsula and the Miura Peninsula.

\section{嶺岡带の極めて Mg に富むダナイトについて}

$$
\text { 荒井章司·内田隆 }
$$

二葉県，頜岡带の超塩基性岩体から極めて $\mathrm{Mg}$ に富むダナイトが発見された。とのダナイトの初生鉱物は， カンラン石とクロムスピネルである。カンラン石は極めて Mg に富んでお゙り F $\mathrm{O}_{94}$ を越える(平均 $\mathrm{Fo}_{84-2}$ )。乙 のダナイトと平衡にあった液は，Roeder と Emslie(1970) により，極めて $\mathrm{Mg}$ に富んでいた $\left(\mathrm{Mg} / \mathrm{Mg}+\mathrm{Fe}^{2+}\right.$ 原 子比で 0.83) 事になる。この様なマグマは、コマチアイト的なるのか，もしくは，する種のピクライト䒺武岩 質のるのであろら。搷岡帯に露出しているピクライト玄武岩は, $\mathrm{Mg} / \mathrm{Mg}+\mathrm{Fe}^{*}$ (全鉄) 原子比が 0.83 前後あり， その橡なるのの有力な候補であろう。 